\begin{tabular}{l|l|l|l|l} 
JOURNAL OF PETROLOGY & VOLUME 42 & NUMBER 1 & PAGES 159-172 & 2001
\end{tabular}

\title{
A Non-cognate Origin for the Gibeon Kimberlite Megacryst Suite, Namibia: Implications for the Origin of Namibian Kimberlites
}

\author{
G. R. DAVIES ${ }^{1 *}$, A. J. SPRIGGS ${ }^{2}$ AND P. H. NIXON ${ }^{2}$ \\ 'FACULTEIT DER AARDWETENSCHAPPEN, VRIJE UNIVERSITEIT, DE BOELELAAN 1085, 1081 HV AMSTERDAM, \\ THE NETHERLANDS \\ ${ }^{2}$ SCHOOL OF EARTH SCIENCES, UNIVERSITY OF LEEDS, LEEDS LS2 9JT, UK
}

REGEIVED DEGEMBER 17, 1999; REVISED TYPESGRIPT AGGEPTED JUNE 28, 2000

\begin{abstract}
Trace element and $\mathrm{Sr}-\mathrm{Nd}-\mathrm{Pb}$ isotope analyses are presented on unaltered kimberlites and clinopyroxenes and garnets of the low-Cr megacryst suite from the Gibeon Province, Namibia. Significant $\mathrm{Sr}$ and $\mathrm{Pb}$ isotope disequilibrium between the kimberlites and megacrysts establishes that the megacrysts are not cognate material. Calculated equilibrium melts for the megacrysts have rare earth element contents comparable with those of alkali basalts. $\mathrm{R} b-\mathrm{Sr}$ mica ages, $\sim 72 \mathrm{Ma}$, demonstrate that kimberlite volcanism occurred between 5 and 10 my after the inferred passage of the Discovery plume beneath the Gibeon region. $\mathrm{Sr}-\mathrm{Nd}-\mathrm{Pb}$ isotope relationships of the kimberlite and megacrysts are distinct from that of the inferred plume and hence it is argued that the plume contributed little mass to the volcanism. The megacryst suite has a strong DUPAL Pb isotope signature. Two hypotheses can explain the genesis of the kimberlite and megacryst suites. The first is that the DUPAL Pb isotope signature is derived from the lower mantle. The megacryst suite therefore represents the high-pressure crystallization product of deep plume-related magmatism. This magmatism interacts with the sub-continental lithospheric mantle (SCLM) to produce the kimberlite magmatism. Alternatively, fluid-rich melts derived from the Discovery plume migrated under the lithosphere and become concentrated in areas that were recently thermally perturbed asthenosphere, causing small degrees of melting and kimberlite magmatism. In this scenario the megacrysts represent polybaric fractionation products from 'basaltic' asthenospheric-derived melts that ponded at the base of, but underwent interaction with, the subcontinental lithosphere. Storage of the megacrysts for an extended period $(>10$ and $<100 \mathrm{my})$ is required to explain the homogeneous
\end{abstract}

major and trace element compositions of individual megacrysts. Currently the latter explanation is favoured, on the assumption that the DUPAL geochemical signal is derived from the SCLM.

KEY WORDS: megacryst; Namibia; kimberlite; $\mathrm{Sr}-\mathrm{Nd}-\mathrm{Pb}$ isotopes

\section{INTRODUGTION}

Kimberlites have been subdivided into Group I (basaltic) and Group II (micacous) on the basis of their petrography and geochemistry (Smith, 1983). Low Crmegacrysts are a characteristic of the majority of Group I kimberlites. These megacrysts, also termed discrete nodules, comprise large $(>1 \mathrm{~cm})$, rounded, fractured single crystals. Mutual inclusions and lamella intergrowths define a suite that consists predominantly of pyrope garnet, magnesian ilmenite (picro-ilmenite), clinopyroxene (sub-calcic to varying degrees), orthopyroxene, zircon and possibly olivine. These minerals are compositionally distinct from those found in associated peridotite xenoliths, which coupled with different deformation rules out derivation from peridotites or eclogites (e.g. Mitchell, 1987). The association with kimberlite, plus the homogeneity of single crystals, which can be up to $40 \mathrm{~cm}$ across, led workers to 
\begin{tabular}{l|l|l|l} 
JOURNAL OF PETROLOGY & VOLUME 42 & NUMBER 1 & JANUARY 2001
\end{tabular}

propose a cognate origin for the megacrysts (e.g. Nixon et al., 1963; Nixon \& Boyd, 1973; Pasteris et al., 1979). These workers invoked megacryst crystallization from the host kimberlite over a long period of time. $P-T$ estimates have been made on rare composite nodules and by assuming a cogenetic origin for all megacrystic phases. Such calculations imply equilibration over a large temperature range $\left(1400-1000^{\circ} \mathrm{C}\right)$ at a relatively constant pressure that equates to the base of the mechanical boundary layer of the lithosphere $(50 \mathrm{kbar})$ (e.g. Nixon \& Boyd, 1973; Harte \& Gurney, 1981; Nixon et al., 1981; Schulze, 1987; Hops et al., 1992).

Despite the appeal of a simple model with megacrysts representing high-pressure cogenetic material there remains considerable controversy regarding the origin of megacryst suites. Comparable compositional variations are found in megacryst suites from kimberlites, alnoites and alkali basalts that contain a garnet-bearing suite. This observation suggests that all megacrysts were formed from a common source, which cannot be the host volcanism. Although individual megacrysts are homogeneous, megacrysts from individual intrusions record marked chemical variations. Many workers have reported co-variation in $\mathrm{MgO}$ (gnt, cpx, opx), $\mathrm{CaO}$ (cpx, opx), $\mathrm{Cr}_{2} \mathrm{O}_{3}$ (ilm, cpx, opx) and $\mathrm{TiO}_{2}$ (gnt) as evidence that the megacrysts crystallized from an evolving kimberlitic magma (e.g. Nixon \& Boyd, 1973; Gurney et al., 1979; Schulze, 1987). Kimberlite magmas, however, do not record chemical evidence of significant fractional crystallization (Mitchell, 1986). In addition, in trace element studies it has generally been concluded that the megacryst suite is not in chemical equilibrium with kimberlite (Harte, 1983; R. Jones, 1987). These observations have led to models that propose early fractionation of the megacryst suite during diapiric upwelling, possibly before kimberlite melt separation (Gurney et al., 1979; Harte \& Gurney, 1981; R. Jones, 1987).

Previous isotope studies have shown general similarities between megacrysts and kimberlites (e.g. Kramers, 1977, 1979; Basu \& Tatsumoto, 1980; Smith, 1983; Griffin et al., 2000), although some studies have shown subtle differences (R. Jones, 1987; Hops et al., 1992). In most studies, however, the megacrysts and kimberlites were not from the same intrusion and the kimberlite samples were always affected by lowtemperature alteration. From existing data it is therefore difficult to establish unequivocally if megacrysts are cogenetic with their host kimberlites. We report chemical and isotopic composition of garnet and clinopyroxene megacrysts and unaltered host rocks from the Gibeon Kimberlite Province, to constrain the petrogenesis of the megacryst suite and by implication the processes responsible for formation and modification of the host kimberlites.

\section{REGIONAL GEOLOGY AND SAMPLE PREPARATION}

The Gibeon kimberlite province, Namibia, occupies an area $100 \mathrm{~km}$ by $80 \mathrm{~km}$ centred at $25^{\circ} 30^{\prime} \mathrm{S}$ and $18^{\circ} \mathrm{E}$ (Fig. 1). In excess of 70 kimberlite pipes are known and they tend to occur in NNE-SSW trending clusters suggesting basement control to the intrusion location (Fig. 2). The kimberlite province intrudes part of the Late Precambrian to Cambrian Nama Group and the overlying Carboniferous to Cretaceous Karoo Sequence. The rarely exposed basement, generally referred to as the Namibian Province, was stabilized at $\sim 2 \cdot 1$ Ga (Tankard et al., 1982). This province lies between the Archaean Kaapvaal Craton and the Mid-Proterozoic Namaqua-Natal Belt. There are no direct geophysical data on the crustal thickness in the region. Garnet and two-pyroxene granulite xenoliths yield pressures of $\sim 13$ kbar (Van Heerden, 1984). This suggests a crustal thickness comparable with that of Proterozoic belts $(42 \mathrm{~km})$ and greater than that of the Kaapvaal Craton (35 km; Durrheim \& Green, 1992). Peridotite xenoliths from the Gibeon kimberlites are predominantly coarse-grained garnet lherzolites, although harzburgites, garnet harzburgites and sheared lherzolites have been found (Mitchell, 1984). The peridotites have a significantly different composition from xenoliths from Kaapvaal kimberlites (Hoal et al., 1995). Gibeon peridotites are characterized by higher modal proportions of olivine, possibly reflecting formation as residues following lower degrees of melt extraction than the Archaean lithosphere (Pearson et al., 1994). Re depletion ages from these xenoliths reach $2 \cdot 2 \mathrm{Ga}$ (Pearson et al., 1994; Hoal et al., 1995) comparable with the age of the crust. $P-T$ estimates for the coarse-grained lherzolite xenoliths fall close to the $44 \mathrm{~mW} / \mathrm{m}^{2}$ geotherm between 35 and $50 \mathrm{kbar}$, indicating derivation from the graphite stability field (Franz et al., 1996). Sheared lherzolites have equilibrated over a similar pressure range but on an elevated geotherm $\sim 50 \mathrm{~mW} / \mathrm{m}^{2}$ (Mitchell, 1984; Franz et al., 1996). Combined gravity and teleseismic studies indicate that there is a decrease in the thickness of the subcontinental lithospheric mantle (SCLM) westward across Namibia away from the Kaapvaal Craton (e.g. Fairhead \& Reeves, 1976). Heat flow measurements also imply thinner lithosphere in central and western Namibia (M. Jones, 1981, 1987).

Kimberlite is extremely vulnerable to alteration (e.g. Fesq et al., 1975; Clement, 1982; Smith, 1983; Mitchell, 1986) such that fresh material can only be obtained from underground mines or drill cores. In addition, kimberlites tend to contain xenolith material derived from the crust and mantle. Namibian kimberlites typically contain 5$15 \%$ crustal material. Several hundred kimberlite drill cores were studied for obvious signs of alteration, and samples with calcite veins and altered olivines were 


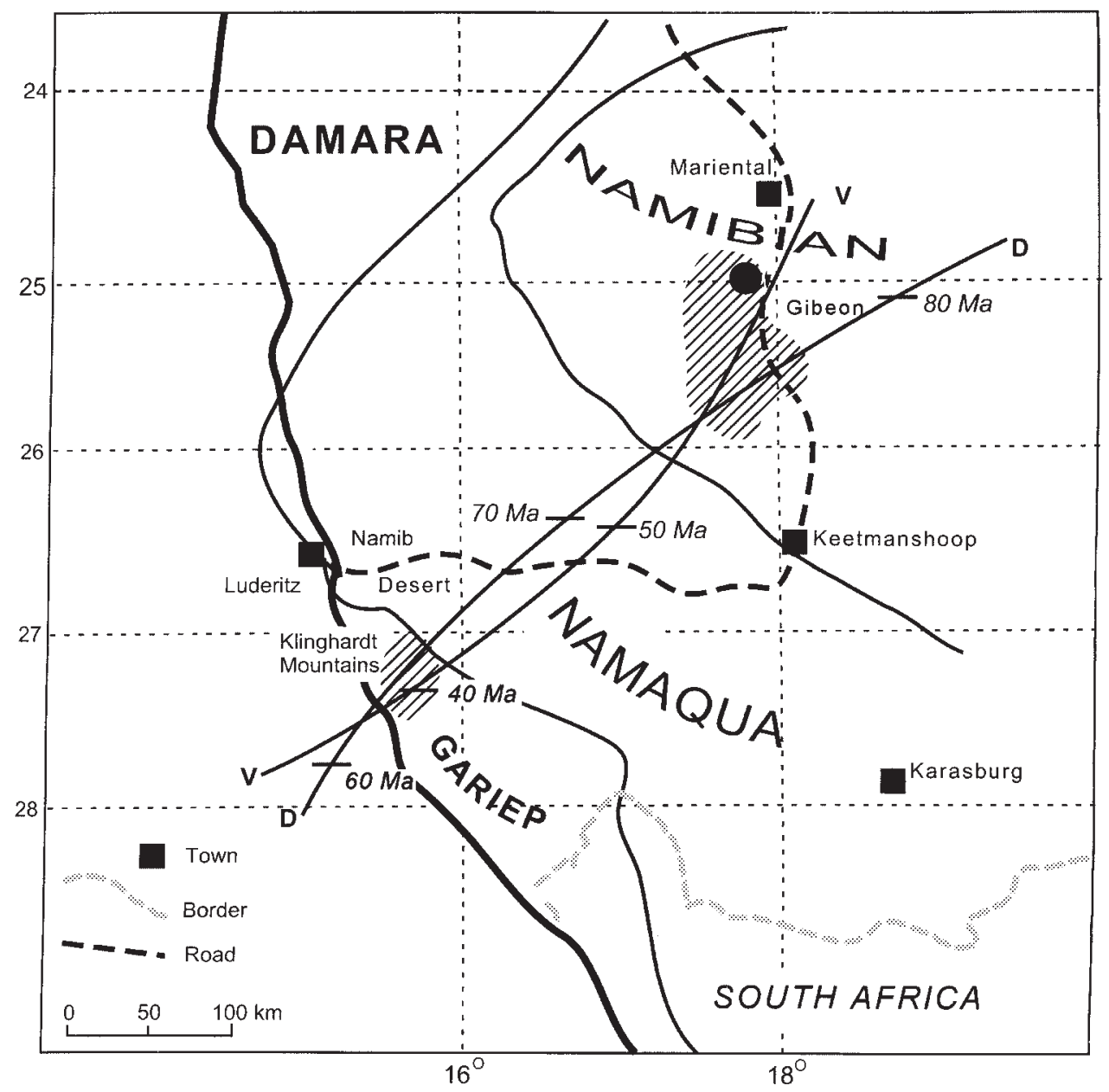

Fig. 1. Generalized location map of Namibia showing the distribution of volcanic rocks. The names of the major tectono-magmatic crustal provinces are shown in upper-case letters. Regions of volcanism marked by lined pattern. Continuous curves representing the tracks of the Vema (V) and Discovery (D) hotspots are from Hartnady \& LeRoex (1983).

rejected. Subsequent petrographic examinations established samples with their primary kimberlite assemblage partially replaced by calcite, chlorite, serpentine, silica or clay minerals. Primary calcite and serpentine were identified on textural grounds. Petrographically unaltered samples were obtained only from drill cores that penetrated four kimberlites of hypabyssal facies. The petrology of each kimberlite locality is variable, implying either a very heterogeneous magma or that each locality contains several different intrusions. Multiple intrusions of kimberlite into the same pipe are a well-known phenomenon. Consequently, each sample is treated individually $(n=16)$. Core samples were coarsely crushed and crust and mantle xenoliths removed. Macrocrystic phlogopites were separated from the kimberlite and leached in $2 \mathrm{M} \mathrm{HCl}$ for $10 \mathrm{~min}$ to remove any carbonate. Although fine-grained groundmass phlogopites are present in some samples, it proved impossible to obtain multiple unaltered, inclusion-free separates of this material.

Garnet and clinopyroxene megacrysts were collected from the surfaces of seven diatreme facies kimberlites (Fig. 2; see Table 3, below). Unaltered megacrysts were selected to ensure no disruption of parent-daughter isotope ratios through alteration or interaction with the host kimberlite, which has concentrations of some trace element several orders of magnitude higher than the megacrysts. All samples were crushed, sieved and washed before hand picking under liquids. All mineral separates were treated ultrasonically in $6 \mathrm{~N} \mathrm{HCl}$ and subsequently washed several times in quartz-distilled $\mathrm{H}_{2} \mathrm{O}$. Sr isotope analyses were not performed on garnet megacrysts because the quality of the analyses is difficult to assess. This is due to garnets having extremely low $\mathrm{Rb}$ and $\mathrm{Sr}$ contents $(<0 \cdot 1 \mathrm{ppm})$, which makes them particularly susceptible to alteration. In addition, minor leaching during acid 
\begin{tabular}{l|l|l|l} 
JOURNAL OF PETROLOGY & VOLUME 42 & NUMBER 1 & JANUARY 2001
\end{tabular}

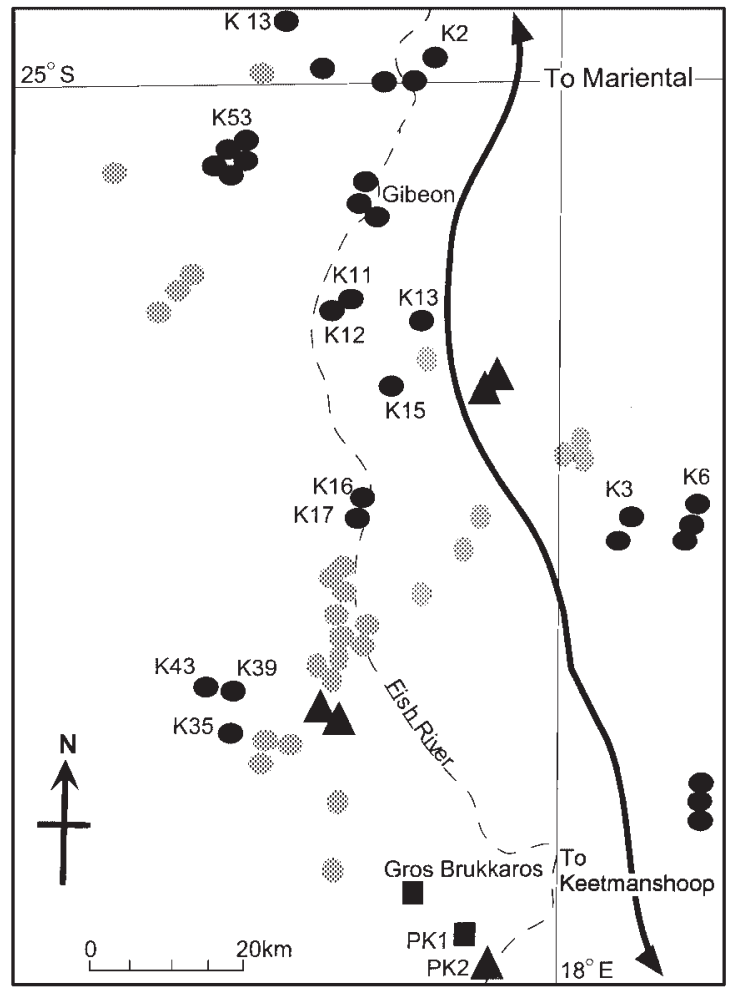

Fig. 2. Generalized location map of kimberlites in the Gibeon Province. Grey ellipses, kimberlites; filled ellipses, sampled kimberlites. Sample numbers indicate localities from which fresh samples or megacrysts were obtained. $\square$, carbonatite; $\triangle$, associated melilitites. PK1 and PK2 are respectively carbonatite and monticellite peridotite dykes from the Blue Hills area for which fresh samples have been obtained.

treatment may significantly disrupt parent-daughter ratios, resulting in incorrect initial ratios.

A detailed discussion of the major element variations exhibited by the megacryst suite is beyond the scope of this study. Previous workers (Mitchell, 1987; Spriggs, 1988) have established that Namibian diopside and garnet megacrysts have large compositional ranges and concluded that, as a whole, the megacryst suite is generated by cumulate processes during the fractional crystallization of several batches of magma. Each kimberlite pipe in the Gibeon Province has its own characteristic megacryst suite that may have a large compositional range. For example, the Mukorob suite contains clinopyroxene with $\mathrm{Ca} /(\mathrm{Ca}+\mathrm{Mg})$ ratios that vary from $0 \cdot 35$ to 0.45 and $\mathrm{Cr}_{2} \mathrm{O}_{3}$ contents of $0 \cdot 1-0 \cdot 9 \%$. Such large compositional ranges imply formation from two or more magmatic sources.

\section{ANALYTIGAL TEGHNIQUES}

Major and trace element data were determined by a combination of X-ray fluorescence (XRF) and inductively coupled plasma mass spectrometry (ICP-MS) at the University of Leeds and instrumental neutron activation analysis (INAA) at the Open University. Rare earth elements (REE) were determined on mineral separates by isotope dilution with standard ion exchange procedures (Thirlwall, 1982). Nd, Sr and $\mathrm{Pb}$ were measured at the University of Leeds. Data were normalized to ${ }^{87} \mathrm{Sr} /{ }^{86} \mathrm{Sr}$ of 0.71024 for NBS 987 and 0.511845 for La Jolla. The routine total blanks at Leeds were $\mathrm{Sr}<2 \mathrm{ng}, \mathrm{Nd}<0 \cdot 2$ $\mathrm{ng}$ and $\mathrm{Pb}<0.25 \mathrm{ng}$. Between 100 and $150 \mathrm{mg}$ of clinopyroxene was analysed for $\mathrm{Pb}$ isotopes. Sample sizes were sufficiently large that no significant blank correction is required. Further analytical details are given in Table 3 (below).

\section{EMPLAGEMENT AGES OF NAMIBIAN KIMBERLITES}

To compare the $\mathrm{Sr}-\mathrm{Nd}-\mathrm{Pb}$ isotope systematics of the kimberlite and megacrysts the time of kimberlite eruption must be known to sufficient precision to allow comparison of initial isotopic ratios. The relatively low parent/daughter ratios of the kimberlites and clinopyroxene megacrysts means that initial $\mathrm{Sr}-\mathrm{Nd}-\mathrm{Pb}$ ratios can be compared provided ages are known to better than \pm 20 my. Better precision is required to evaluate the relationship of the kimberlite volcanism to known hotspot tracks and to determine initial $\mathrm{Nd}$ isotope ratios of garnet megacrysts with high $\mathrm{Sm} / \mathrm{Nd}$ ratios. Here, we report results of a $\mathrm{Rb}-\mathrm{Sr}$ isotope study of phlogopitic micas from four Gibeon kimberlites. The low concentration of phlogopite in Gibeon kimberlites precludes the use of different size fractions to define a mineral isochron. Whole rockmineral pairs are used to define two-point isochrons.

The $\mathrm{Rb}-\mathrm{Sr}$ isotope results are presented in Table 1 (see Fig. 3). The macrocrystic phlogopites have ${ }^{87} \mathrm{Rb} /$ ${ }^{86} \mathrm{Sr}$ ratios that range from $6 \cdot 7$ to $92 \cdot 7$. This large range is due to significant variations in $\mathrm{Rb}(210-500 \mathrm{ppm})$ and $\mathrm{Sr}(17 \cdot 4-163 \mathrm{ppm})$ contents. There is no apparent major element control in phlogopite composition that helps predict high or low $\mathrm{Rb} / \mathrm{Sr}$ ratios. Kimberlite $\mathrm{K} 2$ yields a mineral-whole-rock age of $71.3 \pm 0.4 \mathrm{Ma}$. The phlogopite separate from sample K39 was a composite from several portions of drill core. Consequently, the Sr isotope heterogeneity recorded by the K39 pipe introduces an additional error to the age determination. Calculated ages, which vary from $70 \cdot 9 \pm 0 \cdot 4 \mathrm{Ma}$ to $71 \cdot 3 \pm 0 \cdot 4 \mathrm{Ma}$, are within error of the age determined on kimberlite K2.

Fresh macrocrystalline separates were obtained from two altered kimberlites (K14 and K43). As a result of their altered state, whole-rock data from these kimberlites cannot be used to define an isochron. Below we will demonstrate that there is $\mathrm{Sr}$ and $\mathrm{Nd}$ isotope heterogeneity 
Table 1: $R b-S r$ Isotope data of phlogopites and host rocks

\begin{tabular}{|c|c|c|c|c|c|c|}
\hline Sample & $\mathrm{Rb}(\mathrm{ppm})$ & $\operatorname{Sr}(p p m)$ & $\mathrm{Rb} / \mathrm{Sr}$ & ${ }^{87} \mathrm{Rb} /{ }^{86} \mathrm{Sr}$ & ${ }^{87} \mathrm{Sr} /{ }^{86} \mathrm{Sr}$ & Age \\
\hline \multicolumn{7}{|l|}{ Kimberlites } \\
\hline K2/3/X WR & 137 & 1915 & 0.072 & 0.2069 & $0.705530 \pm 10$ & $71.2 \pm 0.4$ \\
\hline K2 phlogopite* & 210 & 84.56 & $2 \cdot 483$ & $7 \cdot 189$ & $0.712595 \pm 16$ & \\
\hline K39/W/M-WR & 80 & 1264 & 0.063 & 0.1831 & $0.704048 \pm 10$ & $71.5 \pm 0.4$ \\
\hline K39 WR & 81 & 1310 & 0.062 & 0.1788 & $0.704039 \pm 10$ & $71.0 \pm 0.4$ \\
\hline K39 phlogopite* & $376 \cdot 3$ & $163 \cdot 6$ & $2 \cdot 300$ & $6 \cdot 657$ & $0.710634 \pm 10$ & \\
\hline K43 phlogopite* & $552 \cdot 6$ & $17 \cdot 39$ & $31 \cdot 78$ & 92.66 & $0.787873 \pm 18$ & \\
\hline K35 WR & 71 & 1099 & 0.065 & 0.1868 & $0.703801 \pm 10$ & $71.6 \pm 0.4$ \\
\hline K14 phlogopite* & 434.4 & 95.94 & 4.528 & $13 \cdot 11$ & $0.716985 \pm 10$ & \\
\hline K53 WR & 71 & 1089 & 0.065 & 0.1886 & $0.703839 \pm 10$ & $64 \cdot 0 \pm 0.4$ \\
\hline \multicolumn{7}{|c|}{ Gros Brukkaros carbonatite } \\
\hline Carbonate* & 6.57 & 2749 & 0.0024 & 0.0069 & $0.703234 \pm 8$ & $73.6 \pm 0.4$ \\
\hline Phlogopite* & 240.96 & 27.50 & 8.762 & $25 \cdot 40$ & $0.729796 \pm 10$ & \\
\hline
\end{tabular}

* Rb and $\mathrm{Sr}$ determined by isotope dilution. Repetition of standard NBS 607 established that Rb is determined to better than $1 \%$ and $\mathrm{Sr}$ to $<0.1 \%$. $\mathrm{Rb} / \mathrm{Sr}$ ratios determined by XRF on the host kimberlites are also better than $1 \%$. Consequently a conservative error estimate of $1 \%$ is used in isochron calculations.

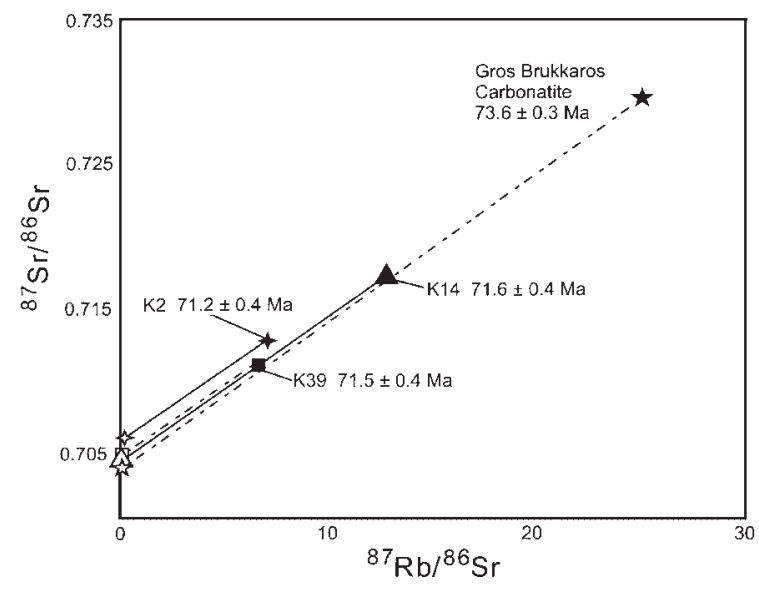

Fig. 3. $\mathrm{Rb}-\mathrm{Sr}$ isochron diagram for phlogopitic micas from Gibeon kimberlites and the Gross Brukkaros carbonatite. Phlogopites represented by filled symbols. Open symbols are whole rocks.

in the kimberlites, possibly with a regional control. Therefore, to help constrain the eruption age of these two altered kimberlites we have used whole-rock $\mathrm{Rb} / \mathrm{Sr}$ data from the nearest unaltered kimberlite. The phlogopite from $\mathrm{K} 14$ has an $\mathrm{Rb} / \mathrm{Sr}$ ratio comparable with those of $\mathrm{K} 2$ and K39 and combined with a whole-rock analysis from the nearest fresh kimberlite (K53) yields an age of $71 \cdot 6 \pm 0 \cdot 4 \mathrm{Ma}$, indistinguishable from those of pipes $\mathrm{K} 2$ and K39. Phlogopite from K43 has the most radiogenic ${ }^{87} \mathrm{Sr} /{ }^{86} \mathrm{Sr}$ ratio obtained in this study, 0.7879. Two analyses of K35, an adjacent kimberlite, are essentially identical (see Table 3). The whole-rock phlogopite age of $\mathrm{K} 43$ is $64 \pm 0.3 \mathrm{Ma}, 7$ my younger than the other samples. This younger age has three possible interpretations: (1) kimberlite magmatism in the Namibian Province was diachronous; (2) the extensive alteration of the kimberlite also disrupted the $\mathrm{Rb} / \mathrm{Sr}$ systematics of the phlogopite; (3) we have made an invalid assumption regarding the unaltered whole-rock ${ }^{87} \mathrm{Sr} /{ }^{86} \mathrm{Sr}$ ratio of K43. To obtain an older eruption age for K43 requires a lower whole-rock ${ }^{87} \mathrm{Sr} /{ }^{86} \mathrm{Sr}$ ratio. K35 has the least radiogenic ${ }^{87} \mathrm{Sr} /{ }^{86} \mathrm{Sr}$ ratio of the Namibian kimberlites and in Namibia only younger carbonatites have lower ${ }^{87} \mathrm{Sr} /{ }^{86} \mathrm{Sr}$ ratios $(0 \cdot 7032$, e.g. Table 1; Spriggs, 1988). To produce a mica age close to $70 \mathrm{Ma}$ an unrealistic wholerock ratio of $<0.700$ is required. From the above data it is impossible to distinguish between the possibility of diachronous volcanism and disruption of the $\mathrm{Rb} / \mathrm{Sr}$ systematics of the phlogopite. However, a 73.6 $\pm 0.4 \mathrm{Ma}$ $\mathrm{Rb}-\mathrm{Sr}$ biotite age for the adjacent Gross Brukkaros carbonatite complex (Table 1) appears to argue against significant diachronism in the regional volcanism.

Three micas define $\mathrm{Rb} / \mathrm{Sr}$ ages that range from $71 \cdot 0$ to $71.6 \mathrm{Ma}$. Consequently, we feel confident in proposing an eruption age for the Gibeon kimberlites of $\sim 71.5 \mathrm{Ma}$. It is important to note that the conclusions reached in the combined $\mathrm{Sr}-\mathrm{Nd}-\mathrm{Pb}$ isotope study of kimberlites and megacrysts presented below are unaffected by uncertainties of $\pm 5 \mathrm{Ma}$ in the emplacement age of the kimberlites. 
\begin{tabular}{l|l|l|l} 
JOURNAL OF PETROLOGY & VOLUME 42 & NUMBER 1 & JANUARY 2001
\end{tabular}

\section{MEGAGRYST REE DATA}

There is a marked variation in the REE concentrations of garnet megacrysts (e.g. $\mathrm{Yb}$ contents range from 0.5 to 10.6 ppm; Table 2, Fig. 4a). Despite the large absolute REE variations there is little variation in REE fractionation; Sm/Nd ratios vary from 0.88 to 0.96 . The clinopyroxene megacrysts also have significant variation in absolute REE abundance (Yb 0.12-0.17 ppm) with little variation in REE fractionation; $\mathrm{Sm} / \mathrm{Nd}$ ratios vary from $0 \cdot 253$ to $0 \cdot 256$ (Fig. 4b). Clinopyroxenes are characterized by positive $\mathrm{Eu}$ anomalies (Eu*/Eu up to $1 \cdot 1$ ) but garnets have no significant anomalies. Recent experimental studies have demonstrated that clinopyroxene will preferentially incorporate $\mathrm{Eu}^{2+}$ compared with other REE under oxidizing conditions and result in positive Eu anomalies (Wood et al., 1999). The Namibian data therefore suggest that the clinopyroxenes crystallized at relatively high oxygen fugacity. By assuming that the megacryst suite is cogenetic, the REE data can be used to estimate clinopyroxene-garnet (cpx-gnt) REE partition coefficients. The calculated partition coefficients vary by over an order of magnitude for all REE (e.g. Nd 1-39; $\mathrm{Yb}$ 0.01-0.3). In contrast, published REE data for eclogites and garnet pyroxenites show limited $K_{\mathrm{d}}$ variation (e.g. Nd 2-9; Pearson et al., 1993; Harte \& Kirkley, 1997). The extreme variability of the REE cpx-gnt partition coefficients from Namibia strongly implies that they do not represent a cogenetic suite. Moreover, the clinopyroxenes record consistent heavy REE (HREE) fractionation. This observation clearly rules out clinopyroxene crystallization from magmas that had fractionated variable amounts of garnet and zircon. Although zircon is probably one of the latest phases to occur on the liquidus of the parental magma, even small amounts $(<5 \%)$ of garnet fractionation would significantly fractionate light REE (LREE) from HREE in the residual liquid.

\section{Sr-Nd-Pb ISOTOPE SYSTEMATIGS OF NAMIBIAN KIMBERLITES AND MEGAGRYSTS}

The four kimberlite pipes have considerable variation in initial $\mathrm{Sr}$ and $\mathrm{Nd}$ isotope ratios; $\varepsilon_{\mathrm{Nd}}+1.6$ to $+4 \cdot 0 ; \varepsilon_{\mathrm{Sr}}$ -14 to +10 (Table 3, Fig. 5). These data are comparable with those for Group I kimberlites, to which the Namibian kimberlites have strong whole-rock chemical affinities (Smith, 1983; Fraser et al., 1985; Smith et al., 1985). Although pipe $\mathrm{K} 2$ has similar $\mathrm{Nd}$ isotope ratios to the other pipes it has ${ }^{87} \mathrm{Sr} /{ }^{86} \mathrm{Sr}$ ratios that trend to values more radiogenic than Group I kimberlites (Fig. 5). Compared with other Namibian kimberlites and typical Group I kimberlites, $\mathrm{K} 2$ has higher $\mathrm{Ba}, \mathrm{Rb}, \mathrm{Sr}, \mathrm{K}$ and $\mathrm{P}$ concentrations (Spriggs, 1988). The style of trace element enrichment (e.g. higher $\mathrm{K} / \mathrm{Nb}, \mathrm{K} / \mathrm{Ti}$ and $\mathrm{Ba} / \mathrm{Nb}$ ) is similar to, although less extreme than, that of Group II kimberlites, which are also generally characterized by relatively radiogenic ${ }^{87} \mathrm{Sr} /{ }^{86} \mathrm{Sr}$ (Fraser et al., 1985).

Present-day and initial $\mathrm{Pb}$ isotope ratios of Namibian kimberlites have relatively high ${ }^{207} \mathrm{~Pb} /{ }^{204} \mathrm{~Pb}$ and ${ }^{208} \mathrm{~Pb} /$ ${ }^{204} \mathrm{~Pb}$ ratios (Fig. 6) comparable with those of Group I kimberlites. Pipe K2 is again transitional towards Group II kimberlite compositions in having less radiogenic ${ }^{206} \mathrm{~Pb}$ / ${ }^{204} \mathrm{~Pb}$. All Namibian kimberlites have high $\mu$ and $\kappa$ values (50-80, 220-310). Pipe K2 has the lowest $\mu$ and $\kappa$ values among the Namibian kimberlite suite. On a ${ }^{207} \mathrm{~Pb} /{ }^{204} \mathrm{~Pb}$ vs ${ }^{206} \mathrm{~Pb} /{ }^{204} \mathrm{~Pb}$ diagram (Fig. 6) initial $\mathrm{Pb}$ isotope ratios of all the kimberlites have high ${ }^{207} \mathrm{~Pb} /{ }^{204} \mathrm{~Pb}$ relative to the Northern Hemisphere Reference Line (NHRL, Hart, 1984) and define an array with a slope sub-parallel to some South Atlantic ocean islands (e.g. Bouvet). The initial $\mathrm{Pb}$ data of the kimberlites are comparable with those for present-day South Atlantic islands (Fig. 6). The initial $\mathrm{Pb}$ isotope data of $\mathrm{K} 2$ overlap in part with the present-day field defined by Gough on ${ }^{207} \mathrm{~Pb} /{ }^{204} \mathrm{~Pb}$ vs ${ }^{206} \mathrm{~Pb} /{ }^{204} \mathrm{~Pb}$ diagram but not on a ${ }^{208} \mathrm{~Pb} /{ }^{204} \mathrm{~Pb}$ vs ${ }^{206} \mathrm{~Pb} /$ ${ }^{204} \mathrm{~Pb}$ diagram.

Clinopyroxene megacrysts have a restricted range in initial $\mathrm{Sr}$ and $\mathrm{Nd}$ isotope ratios $\left(\varepsilon_{\mathrm{Nd}} 2 \cdot 8-4 \cdot 7 ; \varepsilon_{\mathrm{Sr}}-10\right.$ to $-18) . \varepsilon_{\mathrm{Nd}}$ values are generally higher and $\varepsilon_{\mathrm{Sr}}$ lower than for the host kimberlites (Fig. 5). On an $\mathrm{Sr}-\mathrm{Nd}$ isotope co-variation diagram (Fig. 5) the megacrysts plot close to, or slightly below, the 'mantle array'. Figure $5 \mathrm{dem}$ onstrates that only the clinopyroxene megacryst from Deutsche Erde plots within the field of Namibian kimberlites. The clinopyroxene megacrysts define three distinct groups; (1) Mukorob; (2) Hanaus and Koherab; (3) Deutsche Erde. Compared with the total variation of the suite, individual groups have relatively constant $\mathrm{Rb}$ and $\mathrm{Sr}$ concentrations and $\mathrm{Rb} / \mathrm{Sr}$ ratios. There are, however, significant inter-group differences, strengthening the argument for geographic variation (e.g. Mukorob Sr 80·388.5 ppm, Rb/Sr 0.0009-0.00236; Koherab Sr 209-215 $\mathrm{ppm}, \mathrm{Rb} / \mathrm{Sr}$ 0.00703-0.00716). Previously published $\mathrm{Sr}-\mathrm{Nd}$ isotope data from Namibian megacrysts (R. Jones, 1987) are not plotted in Fig. 4 because $\mathrm{Rb} / \mathrm{Sr}$ ratios were not determined and hence no age corrections can be performed. Measured $\mathrm{Sr}$ and $\mathrm{Nd}$ isotope ratios are comparable with those of the present study.

Sm-Nd isotope data for garnet megacrysts are presented in Table 3. The large fractionation in $\mathrm{Sm} / \mathrm{Nd}$ between garnet and clinopyroxene is favourable for obtaining age information. Assessing the degree of garnetclinopyroxene isotopic equilibrium at the time of kimberlite eruption provides an additional test of whether the megacryts and kimberlites are cogenetic. The inferred high equilibration temperature of the minerals implies that they would be above the blocking temperature of the 
\begin{tabular}{l|l} 
DAVIES et al. & GIBEON KIMBERLITE MEGACRYST SUITE
\end{tabular}

Table 2: REE data for Namibian megacrysts

\begin{tabular}{|c|c|c|c|c|c|c|c|c|c|}
\hline & $\mathrm{cp} \times 3$ & $\mathrm{cp} \times 4$ & сpх6 & gnt1 & gnt2 & gnt3 & gnt4 & gnt5 & gnt6 \\
\hline Kimberlite: & K6 & K17 & K6 & K11 & K6 & K15 & K16 & K3 & K13 \\
\hline La & 1.561 & 2.489 & 1.980 & & 0.384 & 0.013 & 0.039 & 0.054 & 0.06 \\
\hline $\mathrm{Ce}$ & $5 \cdot 170$ & $9 \cdot 207$ & 8.023 & & 1.047 & 0.049 & 0.221 & 0.353 & 0.366 \\
\hline $\mathrm{Nd}$ & 4.375 & 9.076 & 5.508 & 3.774 & 1.978 & 0.161 & 1.113 & 1.476 & 1.413 \\
\hline $\mathrm{Sm}$ & 1.106 & 2.321 & 1.401 & 3.541 & 1.737 & 0.155 & 1.003 & 1.389 & 1.285 \\
\hline $\mathrm{Eu}$ & 0.357 & 0.743 & 0.477 & 1.990 & 0.975 & 0.084 & 0.536 & 0.769 & 0.638 \\
\hline $\mathrm{Gd}$ & 0.823 & 1.978 & 1.145 & 8.666 & $4 \cdot 391$ & 0.391 & 2.337 & 3.338 & 3.726 \\
\hline Dy & 0.616 & 1.124 & 0.801 & $17 \cdot 298$ & 8.572 & 0.704 & 4.473 & 7.061 & 5.67 \\
\hline $\mathrm{Er}$ & 0.204 & 0.337 & 0.275 & 11.896 & 5.883 & 0.492 & 2.900 & 4.535 & 3.821 \\
\hline $\mathrm{Yb}$ & 0.121 & 0.165 & 0.154 & 10.559 & 5.587 & 0.472 & 2.692 & 4.411 & 3.696 \\
\hline
\end{tabular}

REE determined by isotope dilution following the technique of Thirlwall (1982). Reproducibility typically better than $1 \%$ for all elements and $\mathrm{Sm} / \mathrm{Nd}$ ratios $<0.2 \%$. La and $\mathrm{Ce}$ of gnt1 are not reported, as underspiking caused excessive error magnification. Sample sizes were typically $>100 \mathrm{mg}$ so no blank correction need be applied. (See Table 3 and Fig. 2 for details of host kimberlite locations.)

isotope systems until the time of eruption. Clinopyroxenes from each pipe have small variations in $\mathrm{Sm}-\mathrm{Nd}$ isotope systematics, which will introduce an error of the order of $\pm 3 \mathrm{Ma}$ in any age determination and immediately suggests that the megacrysts do not simply represent crystallization products of a single magmatic event. Only one garnet sample was analysed from each locality so it is impossible to assess the extent of $\mathrm{Nd}$ isotope heterogeneity of garnets. Garnet-clinopyroxene pairs from the Mukorob II pipe yield Sm-Nd ages between 72 and 78 $\pm 8 \mathrm{Ma}$. Mineral pairs from Koherab and Hanaus yield ages between 55 and $91 \mathrm{Ma}$. Consequently, some ages are consistent with the $\sim 71.5 \mathrm{Ma}$ kimberlite eruption. The large range in $\mathrm{Sm}-\mathrm{Nd}$ garnet-clinopyroxene ages, however, provides further evidence that the two minerals do not have a cogenetic origin with the kimberlite.

The clinopyroxene megacrysts have large variations in $\mathrm{Pb}$ isotope ratios (e.g. ${ }^{206} \mathrm{~Pb} /{ }^{204} \mathrm{~Pb}, 18-19 \cdot 5$, Fig. 5, Table 3) and are characterized by relatively elevated ${ }^{208} \mathrm{~Pb} /$ ${ }^{204} \mathrm{~Pb}$ and ${ }^{207} \mathrm{~Pb} /{ }^{204} \mathrm{~Pb}$ such that they plot above the NHRL of Hart (1984). These data define approximate linear arrays with a relatively restricted range in ${ }^{207} \mathrm{~Pb} /$ ${ }^{204} \mathrm{~Pb}$ but large variations in ${ }^{206} \mathrm{~Pb} /{ }^{204} \mathrm{~Pb}$ and ${ }^{208} \mathrm{~Pb} /{ }^{204} \mathrm{~Pb}$. These arrays overlap in part with basalts from South Atlantic ocean islands and continental flood basalts from Namibia and Brazil (Hawkesworth et al., 1984, 1986, 1988). Measured $\mathrm{U} / \mathrm{Pb}$ ratios of the clinopyroxene megacrysts are low compared with values for the host kimberlite $(\mu=4-22)$. Consequently, comparison with the kimberlite data can only be made after age correction. Coupled variations in initial ${ }^{207} \mathrm{~Pb} /{ }^{204} \mathrm{~Pb}$ and ${ }^{206} \mathrm{~Pb} /{ }^{204} \mathrm{~Pb}$ of the kimberlites and megacrysts are distinct (Fig. 6). We are unable to compare $\left({ }^{208} \mathrm{~Pb} /{ }^{204} \mathrm{~Pb}\right)_{\mathrm{i}}$ ratios as $\mathrm{Th}$ was not determined on the megacrysts. It should be noted, however, that measured ${ }^{208} \mathrm{~Pb} /{ }^{204} \mathrm{~Pb}$ ratios of the megacrysts are generally lower than the initial ratios of the kimberlites, demonstrating that initial ratios will be distinct. The clinopyroxene sample from Deutsche Erde, which has an $\mathrm{Sr}-\mathrm{Nd}$ isotope composition indistinguishable from that of the kimberlites, has a $\mathrm{Pb}$ isotope composition most distinct from that of the kimberlites. Consequently, the combined $\mathrm{Sr}-\mathrm{Nd}-\mathrm{Pb}$ isotope data appear to demonstrate that the kimberlites and megacrysts do not represent a single cogenetic suite.

\section{MEGAGRYST PETROGENESIS REE evidence}

If partition coefficients from the literature are assumed, the REE abundances of the garnet and clinopyroxene megacrysts can be used to estimate the composition of a parental equilibrium liquid. There are few high-pressure REE-garnet or REE-cpx partition coefficients for kimberlitic compositions [see discussion by Wood et al. (1999)] such that it is possible to estimate parental compositions only by assuming that partition coefficients are comparable with those of basaltic systems. Estimated compositions have $\mathrm{Yb}$ concentrations comparable with that of the host kimberlite. The degree of LREE enrichment of the calculated parental liquid is, however, significantly lower than for the host kimberlites $\left(\mathrm{La} / \mathrm{Yb}_{\mathrm{n}} \sim 20 \mathrm{com}-\right.$ pared with 90-110 in host kimberlites; Fig. 4c). These data argue against a genetic relationship between the megacrysts and the kimberlites. Harte (1983) reached a similar conclusion. Kramers et al. (1981), however, argued 
\begin{tabular}{l|l|l|l} 
JOURNAL OF PETROLOGY & VOLUME 42 & NUMBER 1 & JANUARY 2001
\end{tabular}





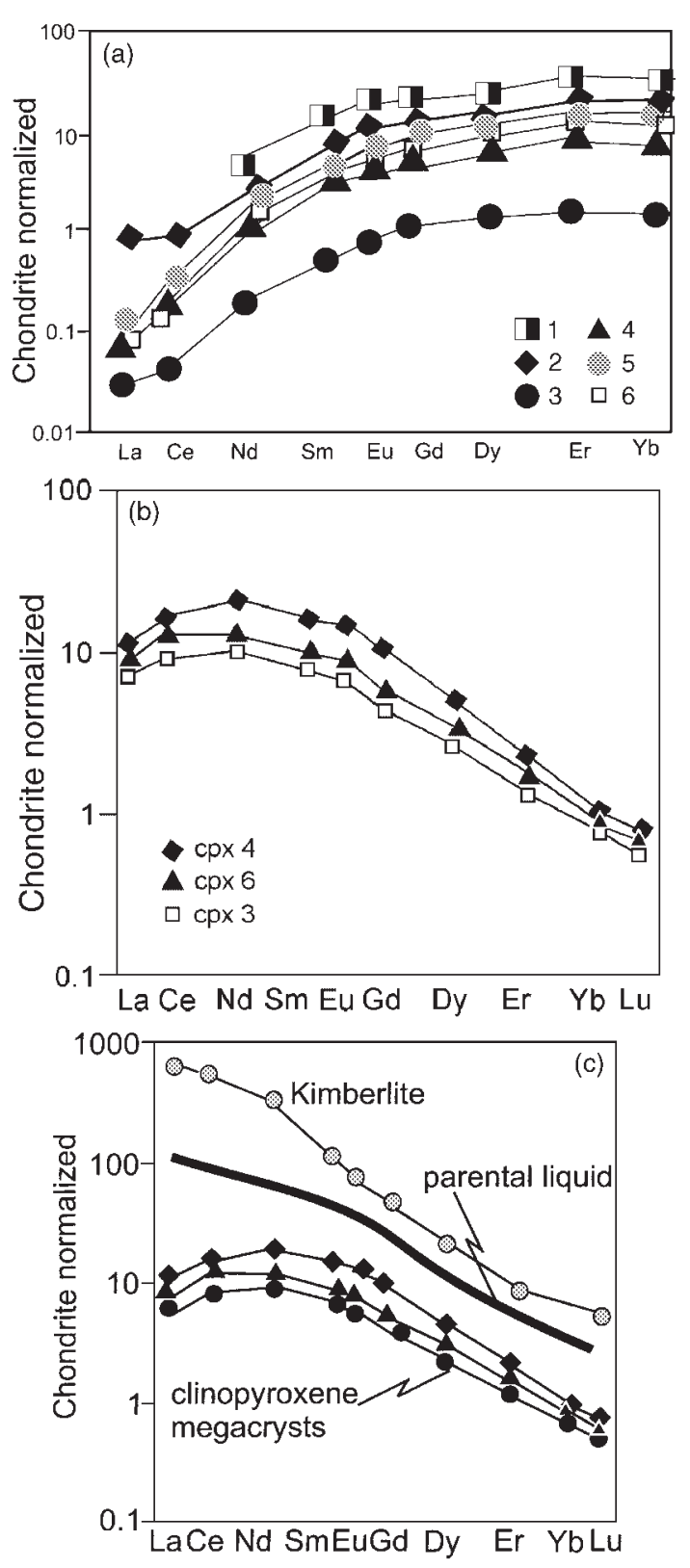

Fig. 4. (a) Chondrite-normalized REE diagram of garnet megacrysts. (See Table 2 for sample localities.) (b) Chondrite-normalized REE diagram of clinopyroxene megacrysts. (See Table 2 for sample localities.) (c) Chondrite-normalized REE diagram depicting difference between the calculated equilibrium liquid for the clinopyroxene megacrysts an the host kimberlite. The marked difference between calculated parental liquid and host kimberlite should be noted.

that because megacryst assemblages are cogenetic with their host kimberlites, clinopyroxene-kimberlite REE partition coefficients were up to an order of magnitude lower than in basaltic systems. To date, no experimental data have been presented to support this supposition.

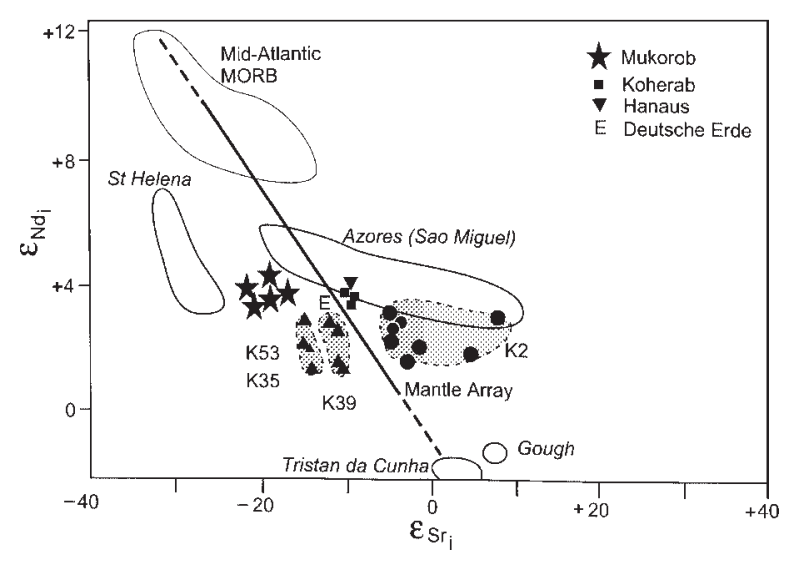

Fig. 5. Initial $\mathrm{Sr}-\mathrm{Nd}$ isotope diagram for Namibian kimberlites and clinopyroxene megacrysts. Kimberlites indicated by small dots (K2) or triangles surrounded by shaded field. Megacrysts have individual symbols depending on locality. Fields of Mid-Atlantic MORB and representative Atlantic OIB taken from Zindler \& Hart (1986), Chaffey et al. (1989) and Davies et al. (1989). Continuous line used for reference represents the 'mantle array' that joins MORB to Bulk Earth.

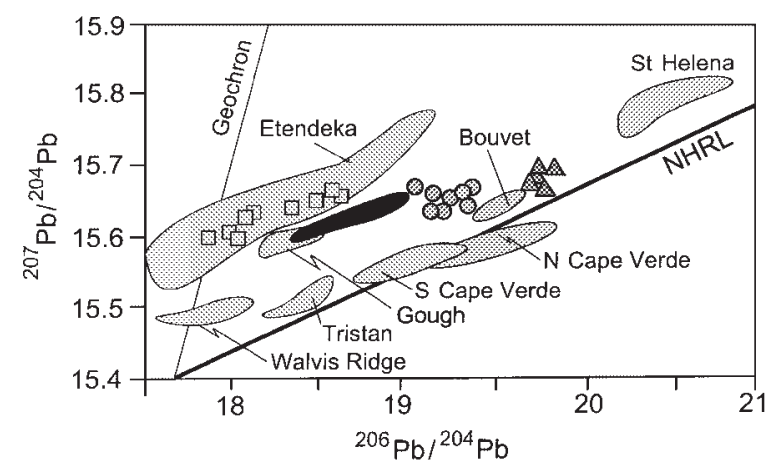

Fig. 6. Present-day and initial ${ }^{207} \mathrm{~Pb} /{ }^{204} \mathrm{~Pb}$ vs ${ }^{206} \mathrm{~Pb} /{ }^{204} \mathrm{~Pb}$ for Namibian kimberlites and clinopyroxene megacrysts. Fields of representative Atlantic OIB taken from Zindler \& Hart (1986) and Davies et al. (1989). Etendeka flood basalts from Hawkesworth et al. (1986, 1988). Grey squares, clinopyroxene megacrysts initial ratios; grey triangles, kimberlites with 'typical' Group I kimberlite characteristics (35, 39, 53); grey circles, kimberlite $\mathrm{K} 2$, which is characterized by chemistry transitional to Group II kimberlite. Initial ratios of the kimberlites plotted as a black field. NHRL, Northern Hemisphere Reference Line.

\section{Combined $\mathrm{Sr}-\mathrm{Pb}-\mathrm{Nd}$ isotope evidence}

The megacrysts and host kimberlites are in $\mathrm{Sr}-\mathrm{Nd}-\mathrm{Pb}$ isotope disequilibrium (Figs 5 and 6). If this relationship is inherited from the mantle then it palpably rules out a cogenetic relationship and hence negates the argument proposed by Kramers et al. (1981) for lower meltclinopyroxene partition coefficients in kimberlitic melts. Before accepting a non-genetic relationship a full assessment of crustal contamination is required. The relatively constant REE slopes of the garnet and clinopyroxene megacrysts imply that any isotope variations are not a consequence of variable contamination by the host 
\begin{tabular}{l|l|l|l} 
JOURNAL OF PETROLOGY & VOLUME 42 & NUMBER 1 & JANUARY 2001
\end{tabular}

kimberlites or fluids derived from them associated with low-temperature alteration. Both processes would tend to introduce an LREE enriched signature to the megacrysts. Namibian kimberlites have high trace element contents (e.g. Sr, $\mathrm{Nd}$ and $\mathrm{Pb}$ contents of 1100, 100 and 5-8 ppm, respectively). Mass balance calculations demonstrate that $10 \%$ crust must be assimilated by the kimberlites to change their ${ }^{87} \mathrm{Sr} /{ }^{86} \mathrm{Sr}$ ratios from that of the megacrysts $(0.7033)$ to an initial ratio of 0.7039 (by assuming an ${ }^{87} \mathrm{Sr} /{ }^{86} \mathrm{Sr}$ ratio of 0.73 for the Proterozoic basement). Given the low $\mathrm{SiO}_{2}$ and high $\mathrm{MgO}$, Cr and Ni contents of the kimberlites this clearly has not occurred. The isotope distinction between megacrysts and kimberlites therefore implies derivation from different sources.

Previous workers have noted apparent isotope disequilibrium between megacrysts and host kimberlite (e.g. Harte, 1983). This difference has been variously ascribed to minor alteration or the early precipitation of the megacryst suite from a 'proto-kimberlitic' melt followed by compositional change in the melt as a result of fractional crystallization and assimilation (e.g. Kramers et al., 1981; R. Jones, 1987). These models are appealing in that they avoid the need for a complex petrogenetic history. Such models are, however, very difficult to reconcile with aspects of megacryst and kimberlite chemical and isotopic compositions. For example, the kimberlites record little evidence of the extraction of the megacryst suite. Fractionation of olivine and spinel would rapidly deplete the magma in $\mathrm{MgO}, \mathrm{Ni}$ and $\mathrm{Cr}$. Clinopyroxene fractionation would deplete Sc and garnet fractionation $\mathrm{Sc}, \mathrm{Ni}$ and HREE. The major element variations recorded by megacryst suites (e.g. Mitchell, 1987) do, however, imply that they formed from a magma that underwent significant fractionation.

The topology of the $\mathrm{Sr}-\mathrm{Nd}-\mathrm{Pb}$ isotope diagrams helps to constrain possible source components in megacryst and kimberlite genesis. $\mathrm{Sr} / \mathrm{Nd}$ ratios of most mantlederived magmas are within the range 10-20 (excluding subduction-related volcanism) such that mixing lines between components on an $\mathrm{Sr}-\mathrm{Nd}$ isotope diagram are close to straight lines. In terms of their $\mathrm{Sr}-\mathrm{Nd}$ isotopes the kimberlites and megacrysts could be explained through some form of mixing process that involves a relatively depleted source [mid-ocean ridge basalt (MORB) or ocean-island basalt (OIB) component] and an enriched component (OIB). The Mukorob megacryst samples have relatively unradiogenic $\mathrm{Sr}$ isotope ratios such that they have characteristics transitional toward HIMU and EM1 ocean islands (e.g. St Helena and Cape Verde, Chaffey et al., 1989; Davies et al., 1989). On Pb/ $\mathrm{Pb}$ diagrams the megacryst suite forms arrays sub-parallel to those of some Atlantic ocean islands and has relatively high ${ }^{207} \mathrm{~Pb} /{ }^{204} \mathrm{~Pb}$ and ${ }^{208} \mathrm{~Pb} /{ }^{204} \mathrm{~Pb}$ ratios that are more extreme than those of Atlantic ocean islands with the DUPAL isotope signature (e.g. Gough, Walvis Ridge and
Cape Verde; Fig. 6). In contrast, HIMU islands generally have radiogenic ${ }^{206} \mathrm{~Pb} /{ }^{204} \mathrm{~Pb}$ and relatively low ${ }^{207} \mathrm{~Pb} /{ }^{204} \mathrm{~Pb}$ and ${ }^{208} \mathrm{~Pb} /{ }^{204} \mathrm{~Pb}$. Consequently, the $\mathrm{Sr}-\mathrm{Nd}-\mathrm{Pb}$ isotope systematics of the megacryst suite is most comparable with that of ocean islands with a DUPAL signature.

In the following discussion petrogenetic models are proposed that assess why the megacryst suite has a DUPAL Pb isotopic signature. It is acknowledged, however, that the combined $\mathrm{Sr}-\mathrm{Nd}-\mathrm{Pb}$ isotopic composition of the megacryst suite is not directly comparable with DUPAL in that Sr isotope ratios are generally less radiogenic. Any proposed model for megacryst kimberlite formation must explain why the megacryst suite has a markedly greater DUPAL $\mathrm{Pb}$ isotope signature than the host kimberlite. In this respect, the source of the DUPAL anomaly is crucial. It is well known that the DUPAL isotopic anomaly is not restricted to the oceanic environment, being present in Parana and Karoo-Etendeka basalts at both margins of the Atlantic (e.g. Hawkesworth et al., 1984, 1988). The origin of the DUPAL chemical and isotopic anomaly has been the subject of considerable debate. Le Roex (1986) proposed that the regional DUPAL anomaly in the Southern Hemisphere was a consequence of asthenospheric derived hotspot magmatism, which also produced Group I and II kimberlites in southern Africa. Weaver et al. (1986) are some of many who have proposed that recycling of sediments into the source of plumes was responsible, whereas Richardson et al. (1984), Hawkesworth et al. (1986) and Davies et al. (1989) argued for an SCLM origin. It is, however, difficult to distinguish between the chemical characteristics of ancient recycled and modified sediments and the SCLM. The strongest evidence for a shallow lithospheric origin of the DUPAL anomaly comes from age information inferred from $\mathrm{Sr}-\mathrm{Nd}-\mathrm{Pb}$ isotopes, which suggests that the sources of continental flood basalts, SCLM xenoliths and the crust are of equal age (Hawkesworth et al., 1984; Pearson, 1999). This observation implies that the entire lithosphere stabilized together. We therefore favour a lithospheric origin for the DUPAL signal. With this assumption a model is proposed to explain the kimberlitemegacryst association (see Fig. 8, below).

Knowledge of the thermal and tectonic processes that have modified the lithosphere in the region and are responsible for the initiation of kimberlite magmatism may be a key to understanding the genetic relationship between the megacryst suite and host rock. Plate reconstructions suggest that several currently active South Atlantic hotspots were initiated and passed beneath southern Africa in the last 200 my (Fig. 7; Duncan, 1981; Morgan, 1983). The latest reconstruction (O'Connor et al., 1999) suggests slower recent motion than previously predicted and that the Discovery plume track was active under the Gibeon province between 75 and $80 \mathrm{Ma}$. Previous magmatism associated with opening of the South 


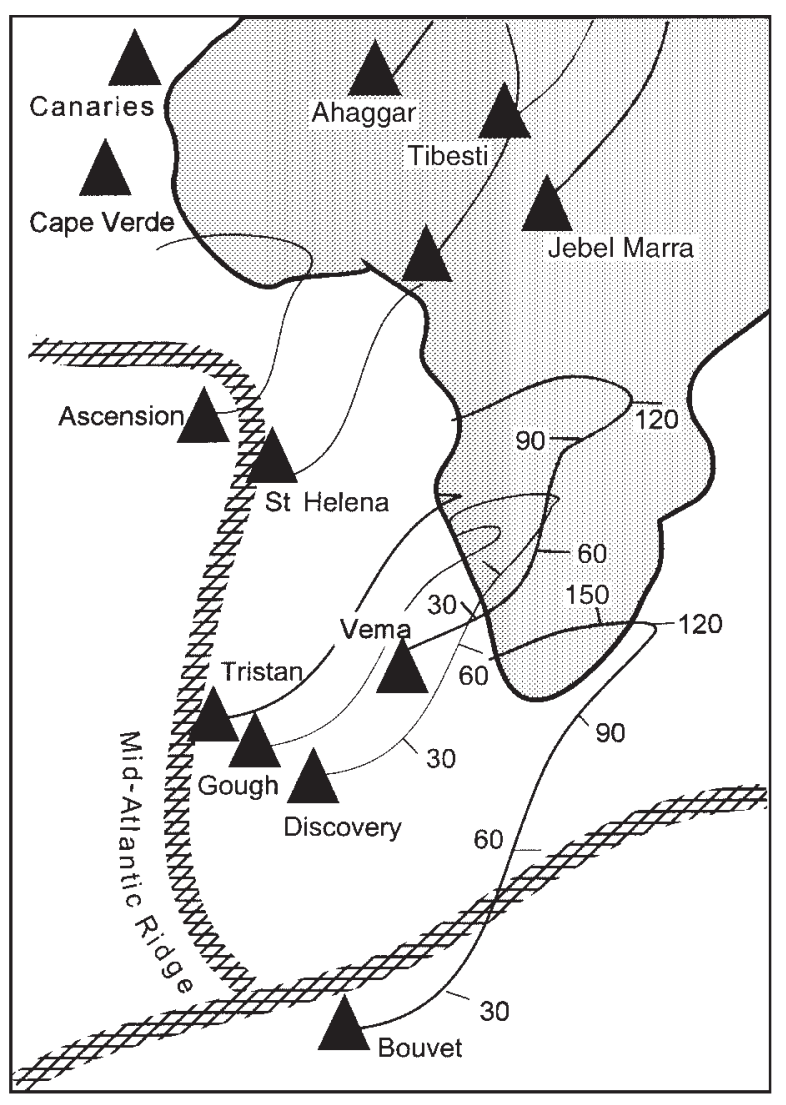

Fig. 7. Schematic figure showing the approximate track of hotspots that have passed beneath southern Africa in the last $200 \mathrm{my}$, from Hartnady \& LeRoex (1983). Before the passage of the Discovery plume beneath Namibia the lithosphere had been modified by magmatic activity associated the Bouvet plume at $\sim 175 \mathrm{Ma}$ and initial formation of the South Atlantic at $\sim 130 \mathrm{Ma}$. The detailed passage of the Vema and Discovery hotspots can be seen in Fig. 1.

Atlantic and the initiation of Tristan and Gough (Etendeka and Parana flood volcanism, Griffiths \& Campbell, 1990) will also have extensively modified the SCLM beneath Namibia. Kimberlite volcanism in Namibia occurs $\sim 5-10$ my after the passage of the Discovery plume beneath the Gibeon region. This time delay and the different $\mathrm{Sr}-\mathrm{Nd}-\mathrm{Pb}$ isotope signature of the current plume-related ocean-island basalts and the Namibian kimberlites suggests that the plume did not act as the direct source of the kimberlites.

The relatively short time delay between the inferred passage of the Discovery plume and kimberlite magmatism implies that the plume is probably ultimately responsible for magma production. The isotopic distinction between the plume and the volcanism, however, establishes that the plume did not provide significant mass to the magmatism. One explanation is that conduction of heat from the hotspot into the thermo-chemical boundary layer at the base of the SCLM resulted in the subsequent

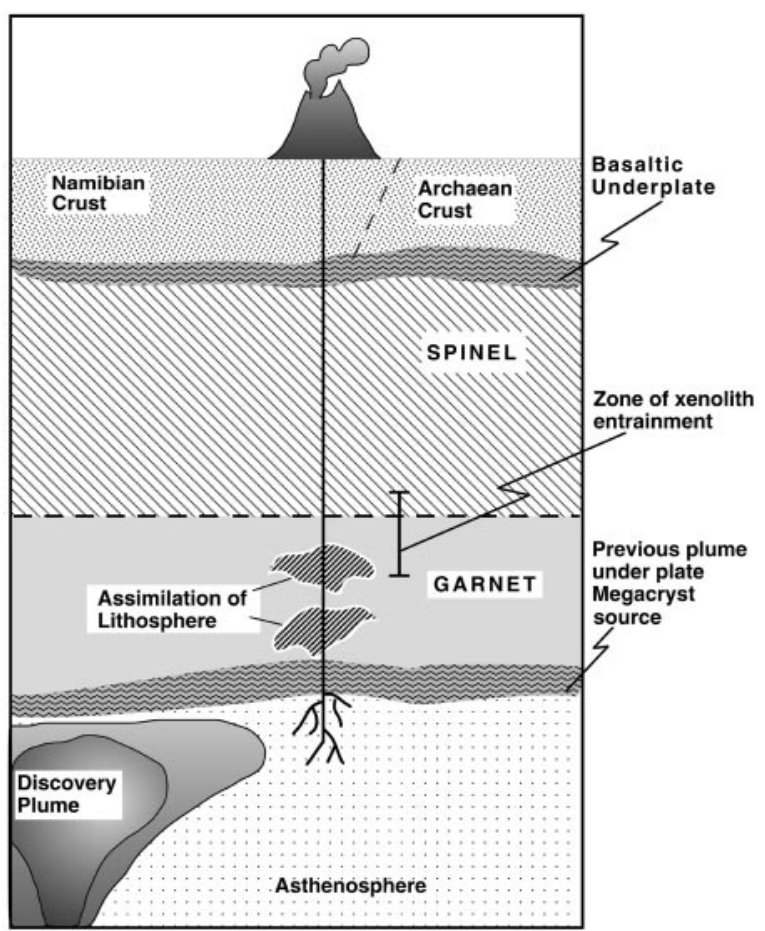

Fig. 8. Schematic model to explain the Gibeon kimberlite-megacryst association. Previous passage of the Discovery plume causes topography at the base of the lithosphere, possibly associated with the tectonic boundary between Namaqua and Namibian aged lithosphere. Fluids from the nearby plume migrate along the base of the SCLM and are concentrated into the recently thermally perturbed asthenosphere causing kimberlite genesis. Kimberlite magmas are variably modified as they pass through the base of the SCLM, assimilating melts derived from the most easily fused parts of the SCLM before rapid emplacement from depth. During emplacement kimberlites incorporate xenoliths from various depths in the lithosphere. The megacryst suite was formed in previous periods of plume-related underplating, most probably at the base of the lithosphere. Residence at relatively high temperatures for $>10$ my is required to explain the homogeneous nature of individual megacrysts.

melting of a shallower non-plume-related source. In this model volatile-rich regions of the SCLM with the lowest solidus temperature would be the source of the kimberlite (Wilson et al., 1995). This argument is not favoured because the isotopic signature of the kimberlites is generally not compatible with an SCLM origin. The exception is kimberlite $\mathrm{K} 2$, which has a composition that is transitional to that of DUPAL, implying some interaction with old trace element enriched lithosphere. Given that xenoliths are transported from above the zone of melt generation, kimberlite formation is inferred to be deeper and hence most probably immediately below the base of the lithosphere (e.g. Le Roex, 1986).

Passage of the Discovery plume will have caused topography at the base of the lithosphere, possibly associated with the tectonic boundary between Namaqua and Namibian lithosphere. A model is proposed wherein fluidrich melts emanating from the plume, which at the time 
\begin{tabular}{l|l|l|l} 
JOURNAL OF PETROLOGY & VOLUME 42 & NUMBER 1 & JANUARY 2001
\end{tabular}

of volcanism was within $\sim 100 \mathrm{~km}$, migrate along the base of the SCLM and are concentrated into the recently thermally perturbed asthenosphere, causing small degrees of melting and kimberlite genesis (Fig. 8). Kimberlite magmas are variably modified as they pass through the base of the SCLM, assimilating melts derived from the most easily fused parts of the SCLM before rapid emplacement from depth (Fig. 8). During emplacement the kimberlites sample xenoliths from various depths in the lithosphere. A test of this hypothesis of kimberlite genesis would be to examine the rare gas isotope ratios of the kimberlite; high ${ }^{3} \mathrm{He} /{ }^{4} \mathrm{He}$ and ${ }^{21} \mathrm{Ne} /{ }^{22} \mathrm{Ne}$ associated with the plume may be transferred to the magmatism even though it is argued that little mass has been. In addition, kimberlites such as $\mathrm{K} 2$ that have characteristics transitional to Group II kimberlites, as a result of inferred assimilation of SCLM, would have a more uranogenic $\mathrm{He}$ and $\mathrm{Ne}$ isotope signature than Group I kimberlites. Unfortunately, widespread alteration of kimberlites and high $\mathrm{U}$ contents mean that only pristine melt-inclusionfree olivines can be used for such a study and such material is difficult to obtain.

The megacryst suite is incorporated into the kimberlite as it migrates through the SCLM. The extreme DUPAL $\mathrm{Pb}$ isotope signature of the megacryst suite implies a significantly greater lithospheric contribution than for the kimberlites. The relatively depleted $\mathrm{Nd}$ and $\mathrm{Sr}$ isotope signature, however, demonstrates that the megacrysts did not simply crystallize from melts of old SCLM. The low $\mathrm{Pb}$ contents of the megacrysts mean that their $\mathrm{Pb}$ isotopes are sensitive to interaction with the SCLM, and high $\mathrm{Sr} / \mathrm{Pb}$ ratios mean that $\mathrm{Sr}$ isotope ratios will not record an SCLM signature unless $>10 \%$ SCLM material is assimilated. Slopes defined by the megacrysts on a ${ }^{207} \mathrm{~Pb} /$ ${ }^{204} \mathrm{~Pb}$ vs ${ }^{206} \mathrm{~Pb} /{ }^{204} \mathrm{~Pb}$ diagram (Fig. 6) are shallower than that of the Etendeka and Parana flood basalts. This observation implies that, in addition to the SCLM, a source with isotopic systematics comparable with South Atlantic Ocean islands such as Bouvet and Ascension was involved in megacryst petrogenesis. On a ${ }^{208} \mathrm{~Pb} /{ }^{204} \mathrm{~Pb}$ vs ${ }^{206} \mathrm{~Pb} /{ }^{204} \mathrm{~Pb}$ diagram (not shown) the megacrysts define a slope that is steeper than that for the flood basalts but shallower than the NHRL and for most OIB. These relationships imply that the megacrysts formed from asthenospheric-derived melts that have undergone extensive crystallization within and contamination by the SCLM (Fig. 8). We therefore favour megacryst formation within and immediately above the thermo-chemical boundary layer at the base of the SCLM that, beneath Namibia, has been extensively modified by the passage of several plumes (Fig. 7). An implication of this model is that the megacryst suite would have He and Ne isotope ratios with a relatively uranogenic signature compared with ambient upper mantle as a result of interaction with the relatively U-enriched SCLM.
The $\mathrm{Pb}-\mathrm{Sr}-\mathrm{Nd}$ relationships outlined above give little direct age information but provide useful constraints on the timing of megacryst formation. The megacrysts have relatively high $\mathrm{Sm} / \mathrm{Nd}$ and low $\mu$ and $\mathrm{Rb} / \mathrm{Sr}$ so that with time the suite records ingrowth in radiogenic ${ }^{143} \mathrm{Nd}$ but little change in $\mathrm{Sr}$ and $\mathrm{Pb}$ isotope ratios. ${ }^{143} \mathrm{Nd}$ in garnets changes, relative to Bulk Earth, at a rate of $\sim 4.5$ $\varepsilon_{\mathrm{Nd}}$ units per 100 my. In addition, radiogenic $\mathrm{Pb}$ growth in the megacrysts has been insufficient to disrupt the shallow $\mathrm{Pb} / \mathrm{Pb}$ array on a ${ }^{207} \mathrm{~Pb} /{ }^{204} \mathrm{~Pb}$ vs ${ }^{206} \mathrm{~Pb} /{ }^{204} \mathrm{~Pb}$ diagram (Fig. 6) despite variable $\mu$ values. The $\mathrm{Nd}$ isotope ratios of the megacrysts are similar to those of many melts recently derived from the asthenosphere. In combination these data are consistent with the megacryst suite having a short but significant residence in the base of the SCLM, $>10$ and <100 my. Major and trace element diffusion during this mantle residence provides the explanation of why individual megacrysts have homogeneous compositions.

The favoured model presented above makes the assumption that the megacrysts have undergone greater interaction with the SCLM than the host kimberlites. Griffin et al. (2000) also favour an SCLM origin for megacrystic zircons based on a Hf isotope study. Mass balance calculations based on $\mathrm{Hf}$ isotope studies of continental crust and depleted mantle suggest that a significant reservoir exists in the Earth with low $\mathrm{Nd} / \mathrm{Hf}$ and non-radiogenic Hf ratios (Blichert-Toft \& Albarède, 1997). Kimberlites and lamproites have such non-radiogenic Hf and low Nd/Hf ratios (Nowell et al., 1998a, $1998 b$ ). These data may potentially be used to distinguish if kimberlites are derived from great depth or from the SCLM (Nowell \& Pearson, 1998). If the SCLM is characterized by non-radiogenic $\mathrm{Hf}$ and low $\mathrm{Nd} / \mathrm{Hf}$ ratios then this would represent the source of kimberlites. If, however, the SCLM reservoir lies on the $\mathrm{Nd}-\mathrm{Hf}$ isotope correlation then a deep mantle source would be favoured in kimberlite genesis. Coupled $\mathrm{Hf}$ and $\mathrm{He}$ isotope studies are under way to substantiate which of the two models is correct.

\section{GONGLUSIONS}

Significant trace element variations within low-Cr megacryst suites from individual kimberlite localities suggest their derivation from a magma, or series of magmas that underwent extensive differentiation. Host kimberlite magmas record no evidence of extensive fractional crystallization of the megacryst suite. Calculated equilibrium melts that may have crystallized the low-Cr megacryst suite have LREE enrichment comparable with that of alkalic basalts not kimberlite. $\mathrm{Sr}-\mathrm{Nd}-\mathrm{Pb}$ isotope disequilibrium between the megacryst and host kimberlites palpably establishes that the megacryst suite is not cognate 
in origin. The generally similar isotopic character of the two rock types, however, implies derivation from a similar source region that, from $P-T$ estimates, must be close to the base of the lithosphere. We favour a model in which megacrysts formed near the base of the SCLM associated with basaltic volcanism. Kimberlite magmatism occurs as a result of the localization of fluid-rich melts derived from the Discovery plume and subsequently entrains the megacrysts. Currently, however, derivation of the DUPAL isotope signature from depths significantly below the SCLM cannot be ruled out. Homogeneous major and trace element compositions and isotope systematics suggest that the megacryst suite had extended residence times at the base of the SCLM, of $>10$ and $<100$ my.

\section{AGKNOWLEDGEMENTS}

Without the drill core samples and field support provided by DeBeers this research project would not have been possible. This paper has benefited from discussion with several colleagues, notably Graham Pearson, Craig Smith and Klaus Mezger. Constructive reviews by Dorrit Jacob and an anonymous reviewer are gratefully acknowledged. A.J.S. was funded by an NERG studentship.

\section{REFERENGES}

Basu, A. R. \& Tatsumoto, M. (1980). Nd isotopes in selected mantle derived rocks and minerals and their implications for mantle evolution. Contributions to Mineralogy and Petrology 75, 43-54.

Blichert-Toft, J. \& Albarède, F. (1997). The Lu-Hf geochemistry of chondrites and the evolution of the mantle-crust system. Earth and Planetary Science Letters 148, 243-258.

Chaffey, D. J., Cliff, R. A. \& Wilson, B. M. (1989). Characterization of the St Helena magma source. In: Saunders, A. D. \& Norry, M. J. (eds) Magmatism in the Ocean Basins. Geological Society, London, Special Publications 42, 257-276.

Glement, C. R. (1982). A comparative geological study of some major kimberlite pipes in the Northern Cape and Orange Free State. Ph.D. thesis, University of Cape Town.

Davies, G. R., Norry, M. J., Gerlach, D. C. \& Cliff, R. A. (1989). A combined chemical and $\mathrm{Pb}-\mathrm{Sr}-\mathrm{Nd}$ isotope study of the Azores and Cape Verde hot-spots: the geodynamic implications. In: Saunders, A. D. \& Norry, M. J. (eds) Magmatism in the Ocean Basins. Geological Society, London, Special Publications 42, 231-255.

Duncan, R. A. (1981). Hotspots in the Southern Oceans - an absolute frame for the motion of the Gondwana continents. Tectonophysics 74, 29-42.

Durrheim, R. J. \& Green, R. W. E. (1992). A seismic refraction investigation of the Archaean Kaapvaal Craton, South Africa, using mine tremors as the energy source. Geophysical fournal International 108, 812-832.

Fairhead, J. D. \& Reeves, C. V. (1976). Teleseismic delay times, Bouguer anomalies and inferred thickness of the African lithosphere. Earth and Planetary Science Letters 36, 63-76.

Fesq, H. W., Kable, E. J. D \& Gurney, J. J. (1975). Aspects of the geochemistry of kimberlites from Premier mine and other S. African occurrences with particular reference to the REE. Physics and Chemistry of the Earth 9, 686-707.

Franz, L., Brey, G. P. \& Okrusch, M. (1996). Reequilibration of ultramafic xenoliths from Namibia by metasomatic processes at the mantle boundary. Contributions to Mineralogy and Petrology 126, 181-198.

Fraser, K. J., Hawkesworth, C. J., Erlank, A. J., Mitchell, R. H. \& Scott-Smith, B. H. (1985). Sr, Nd and $\mathrm{Pb}$ isotopes and trace elements of lamproites and kimberlites. Earth and Planetary Science Letters 76, 57-70.

Griffin, W. L., Pearson, N. J., Belousova, E., Jackson, S. E., van Achterbergh, E., O'Reilly, S. Y. \& Shee, S. R. (2000). The Hf isotope composition of cratonic mantle: LAM-MC-ICPMS analysis of zircon megacrysts in kimberlites. Geochimica et Cosmochimica Acta 64, 133-147.

Griffiths, R. W. \& Campbell, I. H. (1990). Stirring and structure in mantle plumes. Earth and Planetary Science Letters 99, 66-78.

Gurney, J. J., Jakob, W. R. O. \& Dawson, J. B. (1979). Megacrysts from the Monastery kimberlite pipe, South Africa. In: Boyd, F. R. \& Meyer, H. O. A. (eds) The Mantle Sample. Washington, DC: American Geophysical Union, pp. 227-243.

Hart, S. R. (1984). A large scale isotopic anomaly in the southern hemisphere mantle. Nature 309, 753-758.

Harte, B. (1983). Mantle peridotites and processes - the kimberlite sample. In: Hawkesworth, C. J. \& Norry, M. J. (eds) Continental Basalts and Mantle Xenoliths. Nantwich: Shiva, pp. 46-91.

Harte, B. \& Gurney, J. J. (1981). The mode of formation of Cr poor megacryst suites from kimberlites. Fournal of Geology 89, 749-753.

Harte, B. \& Kirkley, H. B. (1997). Partitioning of trace elements between clinopyroxene and garnet: data from mantle eclogites. Chemical Geology 136, 1-24.

Hartnady, C. J. M \& LeRoex, A. P. (1983). Southern Ocean hotspot tracks and the Cenozoic absolute motion of the African, Antarctic and South American plates. Earth and Planetary Science Letters 75, $245-257$.

Hawkesworth, C. J., Marsh, J. S., Duncan, A. R., Erlank, A. J. \& Norry, M. J. (1984). The role of continental lithosphere in the generation of Karoo volcanic rocks. Geological Society of South Africa Special Publication 13, 341-354.

Hawkesworth, C. J., Mantovani, M. M., Taylor, P. N. \& Palacz, Z. (1986). Evidence from the Parana of Brazil for a continental contribution to Dupal basalts. Nature 322, 356-359.

Hawkesworth, C. J., Mantovani, M. M. \& Peate, D. W. (1988). Lithosphere remobilisation during Parana magmatism. Fournal of Petrology (Lithosphere Special Issue) 205-223.

Hoal, B. G., Hoal, K. E. O., Boyd, F. R. \& Pearson, D. G. (1995). Age constraints on the crustal and mantle lithosphere beneath the Gibeon kimberlite field, Namibia. South African Fournal of Geology 98, 112-118.

Hops, J., Gurney, J. J. \& Harte, B. (1992). The Jagersfontein Cr-poor megacryst suite - towards a model for megacryst petrogenesis. Fournal of Volcanology and Geothermal Research 50, 143-160.

Jones, M. Q. W. (1981). Heatflow and heat production studies in the Namaqua mobile belt and Kaapvaal Craton. Ph.D. thesis, University of Johannesburg.

Jones, M. Q. W. (1987). Heatflow and heat production in the Namaqua mobile belt, South Africa. Journal of Geophysical Research 92, 6273-6289.

Jones, R. A. (1987). Sr and $\mathrm{Nd}$ isotopes and REE evidence for the genesis of megacrysts in kimberlites of soutern Africa. In: Nixon, P. H. (ed.) Mantle Xenoliths. Chichester: Wiley, pp. 711-724.

Kramers, J. D. (1977). Pb and Sr isotopes in Cretaceous kimberlites and mantle derived xenoliths from Southern Africa. Earth and Planetary Science Letters 34, 419-431. 


\section{\begin{tabular}{l|l|l|l} 
JOURNAL OF PETROLOGY & VOLUME 42 & NUMBER 1 & JANUARY 2001
\end{tabular}}

Kramers, J. D. (1979). Pb, U, Sr, K, and Rb in inclusion bearing diamonds and mantle derived xenoliths from R.S.A. Earth and Planetary Science Letters 42, 58-70.

Kramers, J. D., Smith, C. B., Lock, N., Harmon, R. S. \& Boyd, F. R. (1981). Can kimberlites be generated from an ordinary mantle? A trace element point of view. Nature 241, 53-56.

Le Roex, A. P. (1986). Geochemical correlations between S. African kimberlites and S. African hotspots. Nature 324, 243-245.

Mitchell, R. H. (1984). Garnet lherzolites from Hanaus-1 and Louwrensia kimberlites of Namibia. Contributions to Mineralogy and Petrology 86, 178-188.

Mitchell, R. H. (1986). Kimberlites; Mineralogy, Geochemistry and Petrology. New York: Plenum.

Mitchell, R. H. (1987). Megacrysts in kimberlites from the Gibeon field, Namibia. Neues Jahrbuch fir Mineralogie, Abhandlungen 157, 267-283.

Morgan, W. J. (1983). Hotspot tracks and the early rifting of the Atlantic. Tectonophysics 94, 123-139.

Nixon, P. H. \& Boyd, F. R. (1973). The discrete nodule association in kimberlites in northern Lesotho. In: Nixon, P. H. (ed.) Lesotho Kimberlites. Cape Town: Cape and Transvaal Printers, pp. 67-75.

Nixon, P. H., von Knorring, O. \& Rooke, J. M. (1963). Kimberlites and associated inclusions of Basutoland: a mineralogical and geochemical study. American Mineralogist 48, 1090-1132.

Nixon, P. H., Rogers, N. W., Gibson, I. L. \& Grey, A. (1981). Depleted and fertile mantle xenoliths from southern African kimberlites. Annual Review of Earth and Planetary Sciences 9, 285-309.

Nowell, G. M. \& Pearson, D. G. (1998). Hf isotope constraints on the genesis of kimberlitic megacrysts: evidence for a deep mantle component in kimberlites. 7th International Kimberlite Conference, Extended Abstracts, University of Cape Town, pp. 634 636.

Nowell, G. M., Kempton, P. D. \& Pearson, D. G. (1998a). Hf-Nd systematics of kimberlites: relevance to terrestrial $\mathrm{Hf}-\mathrm{Nd}$ systematics. 7th International Kimberlite Conference, Extended Abstracts, University of Cape Town, pp. 628-630.

Nowell, G. M., Pearson, D. G., Kempton, P. D., Irving, A. J. \& Turner, S. $(1998 b)$. A Hf isotope study of lamproites: implications for their origin and relationship to kimberlites. 7th International Kimberlite Conference, Extended Abstracts, University of Cape Town, pp. 637-639.

O’Connor, J. M., Stoffers, P., van den Bogaard, P. \& McWilliams, M. (1999). First seamount evidence for a significantly slower African plate motion since 19 to $30 \mathrm{Ma}$. Earth and Planetary Science Letters $\mathbf{1 7 1}$ 575-589.

Pasteris, J. D., Boyd, F. R. \& Nixon, P. H. (1979). The ilmenite association at the Frank Smith mine, R.S.A. In: Boyd, F. R. \& Meyer, H. O. A. (eds) The Mantle Sample. Washington, DC: American Geophysical Union, pp. 256-278.
Pearson, D. G. (1999). The age of continental roots. Lithos 48, 171-194. Pearson, D. G., Davies, G. R. \& Nixon, P. H. (1993). Geochemical constraints on the petrogenesis of diamond facies pyroxenites from the Beni Bousera peridotite massif, North Morocco. Fournal of Petrology 34, 125-172.

Pearson, D. G., Boyd, F. R., Hoal, K. E. O., Hoal, B. G., Nixon, P. H. \& Rogers, N. W. (1994). A Re-Os isotopic and petrological study of Namibian peridotites: contrasting petrogenesis and composition of on- and off-craton lithospheric mantle. Extended Abstract. Mineralogical Magazine 58, 703-704.

Richardson, S. H., Gurney, J. J., Erlank, A. J. \& Harris, J. W. (1984) Origins of diamonds in old enriched mantle. Nature 310, 198-202.

Rogers, N. W., Hawkesworth, C. J., Parker, R. J. \& Marsh, J. S. (1985). The geochemistry of potassic lavas from Vulsini, central Italy, and implications for mantle enrichment processes beneath the Roman region. Contributions to Mineralogy and Petrology 90, 244-255.

Schulze, D. J. (1987). Megacrysts from alkaline volcanic rocks. In: Nixon, P. H. (ed.) Mantle Xenoliths. Chichester: Wiley, pp. 433-452. Smith, C. B. (1983). Pb, $\mathrm{Sr}$ and $\mathrm{Nd}$ isotopic evidence for sources of southern African Cretaceous kimberlites. Nature 304, 51-54.

Smith, G. B., Gurney, J. J., Skinner, E. M. W., Clement, C. R. \& Ebrahim, N. (1985). Geochemical character of S. African kimberlites: a new approach based on isotopic constraints. Transactions of the Geological Society of South Africa 88, 267-280.

Spriggs, A. J. (1988). An isotopic and geochemical study of kimberlites and associated alkaline rocks from Namibia. Ph.D. thesis, University of Leeds.

Tankard, A. J., Jackson, M. P., Eriksson, A. K. A., Hobday, D. K., Hunter, D. R. \& Minter, W. E. L. (1982). Crustal Evolution of Southern Africa. Berlin: Springer.

Thirlwall, M. F. (1982). A triple filament method for rapid and precise analysis of rare earth elements by isotope dilution. Chemical Geology 35, 155-166.

Van Heerden, L. (1984). Lower crustal xenoliths from the Gibeon Kimberlite Province, S.W.A.: an investigation. B.Sc. thesis, University of Cape Town.

Weaver, B. L., Wood, B. J., Tarney, J. \& Joron, J. L. (1986). Role of subducted sediment in the genesis of ocean-island basalts: geochemical evidence from S. Atlantic ocean islands. Geology 14, 275278.

Wilson, M., Rosenbaum, J. M. \& Dunworth, E.-A. (1995). Melilitites; partial melts of the thermal boundary layer? Contributions to Mineralogy and Petrology 119, 181-196.

Wood, B. J., Blundy, J. A. \& Robinson, A. C. (1999). The role of clinopyroxene in generating $\mathrm{U}$-series disequilibrium during mantle melting. Geochimica et Cosmochimica Acta 63, 1613-1620.

Zindler, A. \& Hart, S. R. (1986). Chemical geodynamics. Annual Review of Earth and Planetary Sciences 14, 493-571. 